\title{
Pengaruh Kebutuhan Aktualisasi Diri Dan Beban Kerja Terhadap Prestasi Kerja Karyawan Pada Dinas Perindustrian dan Perdagangan Sumatera Barat
}

\author{
Rejil Seri Utami, Maria Magdalena \\ Sekolah Tinggi Ilmu Ekonomi KBP \\ rejilseriutami@gmail.com
}

\begin{abstract}
In the problem of employee work performance in the West Sumatra industrial and trade department. In the company a productivity that does not support work productivity. the number of employees who do not understand the work done, employees are also not responsible for a job. because of the large amount of work done by employees given by superiors. The purpose of this study is to find out the effects of self-actualization needs and workload on employee performance at the West Sumatra Industry and Trade Office. This type of research is quantitative. The population of this study were employees at the West Sumatra Industry and Trade Office with 41 samples taken in Total Sampling. Data is processed using multiple linear regression using a questionnaire. The results showed that there was an effect of self-actualization needs on work performance with a value of $t$ arithmetic 2,281>t table 2,022, and sig value 0,028<0,05 and t count 2,066, $>t$ table 2,022, and sig value 0,046 <0,05, it could be concluded that Ha is accepted and Ho is rejected means that the workload has a significant and significant effect on work performance decisions and suggestions for further researchers to be able to use this research as a reference which will later provide a comparison in conducting further research
\end{abstract}

Keywords: Self Actualization Needs, Workload, Work Performance.

\section{PENDAHULUAN}

Sumber daya manusia (SDM) di perusahaan perlu dikelola secara profesional agar terwujud keseimbangan antara kebutuhan pegawai dengan tuntutan dan kemampuan organisasi perusahaan. Keseimbangan tersebut merupakan kunci utama perusahaan agar dapat berkembang secara produktif dan wajar. Berkaitan dengan hal tersebut, karyawan merupakan sumber daya penting yang wajib perusahaan jaga, maka perusahaan tersebut dituntut untuk mampu mengoptimalkan kinerja karyawannya. Peran Sumber Daya Manusia (SDM) dalam suatu organisasi memiliki kedudukan yang penting pada proses kerja sejak dari perencanaan, pelaksanaan sampai dengan pencapaian tujuan organisasi.

Setiap organisasi atau perusahaan selalu berupaya agar karyawan yang terlibat dalam kegiatan organisasi atau perusahaan dapat memberikan prestasi kerja setinggi mungkin untuk mewujudkan tujuan yang telah ditetapkan, maka pemeliharaan hubungan yang kontinyu dan serasi dengan para karyawan menjadi sangat penting. Salah satu hal yang penting diperhatikan dalam pemeliharaan hubungan tersebut adalah dengan penilaian prestasi kerja secara kontinyu. Seperti yang dikemukakan oleh Nawawi (2003:36), pada hakekatnya prestasi kerja karyawan yang merupakan kegiatan manajemen Sumber Daya Manusia (SDM) yang merupakan proses pengamatan (observasi) terhadap pelaksanaan pekerjaan oleh seorang pekerja yang memiliki hak-hak asasi yang dilindungi. 
Menurut Adhani (2013)ada 5 kebutuhan dasar manusia yang membentuk hirarki kebutuhan yaitu kebutuhan fisiologis, kebutuhan keamanan, kebutuhan sosial, kebutuhan akan penghargaan, dan kebutuhan aktualisasi diri. Dari kelima kebutuhan tersebut yang dapat meningkatkan motivasi seorang pekerja untuk terus berprestasi yaitu kebutuhan aktualisasidiri. Pemenuhan kebutuhan akan aktualisasi diri merupakan tingkat kebutuhan yang tertinggi. Ketika seseorang telah mencukupi dalam ke-4 kebutuhan di bawahnya maka ia pun akan membutuhkan aktualiasi diri dimana ia diakui sebagai seseorang yang memiliki kontribusi penting atas sebuah perusahaan (Adhani,2013). Jadi dapat disimpulkan, kebutuhan aktualisasi diri akan menimbulkan kepuasan tersendiri dari individu tersebut.

Anita, (2013) mendefinisikan prestasi kerja sebagai tingkat keberhasilan yang mencapai seseorang untuk mengetahui sejauh mana seseorang mencapai prestasi yang diukur atau dinilai. Berdasarkan beberapa pengertian tersebut diatas, penulis menarik kesimpulan bahwa prestasi kerja pada dasarnya lebih menekankan pada hasil yang diperoleh dari sebuah pekerjaan sebagai kontribusi instansi/organisasi tempatnya bekerja. Sasaran penilaiannya antara lain kecakapan, kemampuan pelaksanaan tugas yang diberikan, performa dalam melaksanakan tugas, cara membuat laporan atas pelaksanaan tugas, dan ketegaran jasmani serta rohani selama bekerja.

Prestasi kerja menurut (Adhani, 2013) adalah untuk memotivasi dan meningkatkan keterampilan kerja, termasuk pemberian konseling pada perilaku karyawan dan menindak-lanjuti dengan pengadaan training.

Prestasi kerja adalah suatu hasil kerja yang dicapai oleh seseorang dalam melaksanakan tugas-tugas yang dibebankan kepadanya yang didasarkan atas kecakapan, pengalaman dan kesungguhan serta waktu (AR, 2013). Seiring dengan perkembangan teknologi yang begitu pesat, menyebabkan bertambahnya beban kerja karyawan yang harus diselesaikan oleh karyawan. Para karyawan dituntut untuk dapat bekerja lebih maksimal dan mampu menyelesaikannya dengan batas waktu yang telah ditentukan perusahaan kepadanya.

Dalam permasalahan prestasi kerja karyawan pada dinas perindustrian dan perdagangan sumatera barat. prestasi kerja karyawan tidak sesuai dengan apa yang diharapkan, karena karyawan sering dalam pengerjaanya tidak sesuai target yang telah ditentukan, dan banyaknya karyawan yang tidak memehami pekerjaan yang dilakukannya, karyawan juga tidak bertanggung jawab terhadap suatu pekerjaan. karena banyaknya pekerjaan yang dilakukan oleh karyawan yang diberikan atasan hal ini mengakibatkan menurunnya penilaian kinerja karyawan atau mempengaruhi kinerja karyawan dan prestasi kerja. Beberapa karyawan juga menyebutkan menurunnya kinerja tersebut disebabkan tidak meratanya beban kerja yang diberikan atasan, hal ini akan kurang motivasi karyawan dalam melaksanakan pekerjaanya.

Menurut (Adhani, 2013) dalam Arianto menyatakan aktualisasi diri adalah proses menjadi diri sendiri dan mengembangkan sifat-sifat dan potensi psikologis yang unik, Maslow menemukan bahwa dengan memandang suku asal usul seseorang, setiap manusia mengalami tahap-tahap peningkatan kebutuhan atau pencapaian dalam kehidupannya. Kebutuhan tersebut meliputi kebutuhan fisiologis, kebutuhan keamanan dan keselamatan, kebutuhan sosial, kebutuhan akan penghargaan, dan kebutuhan aktualisasi diri. 
Menurut (Desriana, 2014) kebutuhan aktualisasi diri, yaitu kebutuhan untuk mengembangkan diri dan potensi, mengemukakan ide-ide, memberikan penilaian, kritik, dan berprestasi. Dalam hubungannya dengan kebutuhan ini, pemimpin perlu memberi kesempatan kepada karyawan bawahan agar mereka dapat mengaktualisasi diri secara baik dan wajar dilakukan.

Terdapat dua motif yang berkaitan dengan kebutuhan aktualisasi diri yakni kompetensi dan prestasi. Motif kompetensi terungkap dengan sendirinya pada dewasa ketika tumbuh hasrat untuk menguasai pekerjaan dan keahlian. Motif prestasi. Orang-orang yang bermotivasi prestasi cenderung mengambil jalan tengah dengan menyukai kadar risiko moderat karena mereka merasa bahwa upaya dan kemampuan mereka kemungkinan besar akan mempengaruhi hasil.

Dalam permasalahan Aktualisasi diri pada dinas perindustrian dan perdagangan sumatera barat. Banyaknya pekerja tidak mengembangkan diri terhadap suatu pekerjaan dan kurangnya potensi atau pemikiran dalam suatu pekerjaan.begitu juga karyawan tidak memberikan ide atau pendapat dalam suatu pekerjaan. hal ini akan menimbulkan motivasi yang rendah dan prestasi kerja karyawan yang rendah untuk karyawan menjalankan suatu pekejaannya.

Menurut penelitian yang dilakukan oleh Hauck et al dalam Adhani (2013) menyatakan bahwa penumpukan beban kerja akan mengakibatkan penurunan pada kinerja dan meningkatkan stres kerja, dan juga dari beban kerja yang berlebih juga mengakibatkan produktivitas kerja menjadi turun, karena beban kerja yang berlebih itu menyebabkan tekanan-tekanan yang dapat menimbulkan stres bagi karyawan. Maka dari itu, perusahaan harus terus berupaya memotivasi pekerja untuk dapat mengatasi tekanan-tekanan tersebut sehingga tidak menjadi masalah dalam internal perusahaan yang akan menghambat kinerja karyawan.

Pengertian beban kerja adalah sejumlah kegiatan yang harus diselesaikan oleh suatu unit organisasi atau pemegang jabatan secara sistematis dengan cara menggunakan teknik analisis jabatan, teknik analisa beban kerja, atau teknik manajemen lainnya dalam jangka waktu tertentu untuk mendapatkan informasi tentang efisiensi dan efektifitas kerja suatu unit organisasi (Anita, 2013)

Dalam permasalahan Beban Kerja pada dinas Perindustrian dan Perdagangan sumatera barat. Adanya suatu tekanan pekerjaan dari atasan yang menimbulkan beban pemikiran atau fisik atau mental bagi karyawan. Karena dalam suatu pekerjaan harus di siap tepat waktu yang telah di tentukan oleh atasan. Dalam masalah beban kerja ini, banyak karyawan yang tidak tepat waktu dalam menyelesaikan pekerjaannya. Dari penjelesan yang diatas, apabila beban kerja tidak efektif, maka organisasi dalam dinas Perindustrian dan Perdagangan sumatera barat tidak berjalan dengan baik.

Selanjutnya prestasi kerja merupakan hal yang bersifat individual, karena setiap individu memiliki prestasi kerja yang berbeda sesuai dengan kinerja masing-masing karyawan. Peningkatan prestasi kerja merupakan sasaran utama dari peningkatan kualitas sumber daya manusia. Penilaian prestasi kerja adalah proses dimana organisasi-organisasi mengevaluasi atau menlilai prestasi kerja karyawan (Yusianto, 2008).

Berdasarkan fenomena tersebut peneliti ingin mengetahui dan menganalisis pengaruh kebutuhan aktualisasi diri dan beban kerja terhadap prestasi kerja karyawan pada dinas perindustrian dan perdagangan di sumatera barat, tujuannya untuk membahas dan menganalisis pengaruh kebutuhan aktualisasi diri dan beban 
kerja terhadap prestasi kerja karyawan serta membahas dan menganalisis pengaruh kebutuhan aktualisasi diri dan beban kerja secara bersama-sama terhadap prestasi kerja.

faktor-faktor yang dapat membentuk prestasi kerja adalah faktor kemampuan dan faktor motivasi. sedangkan menurut mulyono yang dapat menentukan prestasi kerja dalam organisasi publik adalah lingkungan, karakteristik, organisasi, karakteristik kerja, dan karakteristik individu. Tujuan dari penilaian pretasi kerja menurut (Adhani, 2013) adalah untuk memotivasi dan meningkatkan keterampilan kerja, termasuk pembelian konseling pada perilaku karyawan dan menindak-lanjuti dengan pengadaan training. Selain itu cherrington menambahkan tujuan lainnya antara lain untuk mengidentifikasi kebutuhan training untuk kepentingan karyawan agar tingkat kemampuan dan keahliannya pada satu pekerjaan dapat di tingkat pada level yang lebih tinggi.

Dari pengertian mengenai aktualisasi diri, beban kerjadan prestasi kerja diatas, dapat disimpulkan bahwa bagus tidaknya prestasi kerja karyawan tergantung pada bagaimana kemampuan memenuhi kebutuhan aktualisasi diri karyawan dan juga bagaimana beban kerja pada karyawan tersebut.

Fenomena prestasi kerja karyawan pada dinas perindustrian dan perdagangan sumatera barat.prestasi kerja karyawan tidak sesuai dengan apa yang diharapkan, karena karyawan sering dalam pengerjaanya tidak sesuai target yang telah ditentukan, banyaknya karyawan yang tidak memehami pekerjaan yang dilakukannya, karyawan juga tidak bertanggung jawab terhadap suatu pekerjaan. karena banyaknya pekerjaan yang dilakukan oleh karyawan yang diberikan atasan hal ini mengakibatkan menurunnya penilaian kinerja karyawan atau mempengaruhi kinerja karyawan dan prestasi kerja. Beberapa karyawan juga menyebutkan menurunnya kinerja tersebut disebabkan tidak meratanya beban kerja yang diberikan atasan, hal ini akan kurang motivasi karyawan dalam melaksanakan pekerjaanya.

\section{Prestasi Kerja}

Mangkunegara dalam Adhani (2013) mendefinisikan prestasi kerja sebagai hasil kerja secara kualiats dan kuantitas yang dicapai oleh seoarang pegawai dalam melaksanakan tugasnya sesuai dengan tanggung jawab yang diberikan kepadanya.

Prestasi kerja yaitu tingkat keberhasilan yang dicapai oleh seseorang atau sekelompok orang dalam melaksanakan dan menyelesaikan tugas-tugas yang dibebankan kepadanya, serta adanya peningkatan kualitas dan kuantitas hasil kerja dari waktu ke waktu dalam mencapai tujuan organisasi (Adhani, 2013).

Adhani (2013) menambahkan bahwa prestasi kerja atau diartikan sebagai tingkat ketrampilan yang diperlukan dalam menyelesaikan suatu pekerjaan yang dirasa penting.

Menurut Gomez penilaian prestasi kerja adalah untuk memotivasikan dan meningkatkan keterampilan kerja, termasuk pembelian konseling pada perilaku karyawan dan menindak-lanjuti dengan pengadaan training. Selain itu cherrington menambahkan tujuan lainnya antara lain untuk mengidentifikasikan kebutuhan training untuk kepentingan karyawan agar tingkat kemampuan dan keahliannya pada suatu pekerjaan dapat ditingkatkan pada level yang lebih tinggi. 


\section{Indikator Prestasi Kerja}

Menurut (Anita(2013) indikator prestasi kerja adalah:

1. Kemampuan kerja

2. Penggunaan waktu kerja

3. Hasil yang diharapkan

4. Sikap ingin meningkatkan kemampuan.

KEBUTUHAN AKTUALISASI DIRI

\section{Pengertian kebutuhan Aktualisasi Diri}

Arianto dalam Adhani (2013) menyatakan aktualisasi diri adalah proses menjadi diri sendiri dan mengembangkan sifat-sifat dan potensi psikologis yang unik, Adhani (2013) mengemukakan bahwa tanpa memandang suku asal-usul seseorang, setiap manusia mengalami tahaptahap peningkatan kebutuhan atau pencapaian dalam kehidupannya. Kebutuhan tersebut meliputi kebutuhan fisiologis, kebutuhan keamanan dan keselamatan, kebutuhan sosial, kebutuhan akan penghargan, dan kebutuhan aktualisasi diri.

Orang yang mampu mengaktualisasikan dirinya sangat memahami bahwa ada eksistensi atau hambatan lain tinggal (inweling) didalam (internal) atau di luar (eksternal) keberadaannya sendiri yang menyesuaikan perilaku dan tindakannya untuk melakukan sesuatu (Adhani, 2013).

Menurut (Adhani (2013) hambatan yang berasal dari dalam diri (internal) adalah ketidaktahuan akan potensi diri dan perasaan ragu dan takut untuk mengungkapkan potensi diri.

Menurut Maslow dalam Nawawi (1970) ada beberapa karakteristik yang menunjukan seseorang mencapai aktualisasi diri, yaitu mampu melihat realitas lebih secara efisien, penerimaan terhadap diri sendiri dan orang lain apa adanya, spontanitas, kesederhanaan dan kewajaran, terpusat pada persoalan, membutuhkan kesendirian, otonomi, (kemandirian terhadap kebudayaan dan lingkungan), kesegaran dan apresiasi yang berkelanjutan, kesadaran sosial, hubungan interpesonal, demokratis kreativitas, indepedensi dan pengalaman puncak (peak experiance).

\section{Karakteristik Kebutuhan Aktualisasi Diri}

Nawawi dalam Adhani (2013) ada beberapa karakteristik yang menunjukkan seseorang mencapai aktualisasi diri, yaitu:

1. Mampu melihat realita secara lebih efisien,

2. Penerimaan terhadap diri sendiri dan orang lain apa adanya,

3. Spontanitas, kesederhanaan dan kewajaran,

4. Terpusat pada persoalan, membutuhkan kesendirian, otonomi (kemandirian terhadap kebudayaan dan lingkungan),

5. Kesegaran dan apresiasi yang berkelanjutan, kesadaran sosial, hubungan interpersonal, demokratis, kreativitas, independensi, dan pengalaman puncak (peak experiance). 


\section{BEBAN KERJA}

\section{Pengertian Beban Kerja}

Beban kerja menurut Adhani, 2013) adalah besaran pekerjaan yang harus dipikul oleh suatu jabatan/unit organisasi dan merupakan hasil kali antara volume kerja dan norma waktu (Utomo, 2008). Menurut Adhani) dalam Utomo (2008), Beban kerja adalah sekumpulan atau sejumlah kegiatan yang harus diselesaikan oleh suatu unit organisasi atau pemegang jabatan dalam jangka waktu tertentu. Pengukuran beban kerja diartikan sebagai suatu teori untuk mendapatkan informasi tentang efisiensi dan efektivitas kerja suatu unit organisasi, atau pemegang jabatan yang dilakukan secara sistematis dengan menggunakan teknik analisis jabatan, teknik analisis beban kerja atau teknik manajemen lainnya.

Menurut (Lituhayu, 2008) beban kerja adalah frekuensi rata-rata masingmasing jenis pekerjaan dalam jangka waktu tertentu. Memperkirakan beban kerja dari masing-masing satuan organisasi dapat dilakukan berdasarkan perhitungan atau berdasarkan pengalaman.

Beban kerja menurut permendagri adalah besaran pekerjaan yang dipukuloleh suatu jabatan atau unit organisasi dan merupakan hasil kali antara volume kerja dan norma waktu (Utomo 2008) dan menurut Menpan (1997) beban kerja adalah sekumpulan atau sejumlah kegiatan yang harus disesuaikan oleh suatu unit organisasi atau pemegang jabatan dalam jangka tertentu.

Moekijat dalam (Lituhayu, 2008) mengemukakan, bahwa analisis beban kerja memberikan informasi tentang syarat-syarat tenaga kerja secara kualitatif serta jenis-jenis jabatan dan karyawan yang diperlukan untuk menyelesaikan tugas-tugas.

Rodahi dalam prihatini (2007) menyatakan bahwa beban kerja dipengaruhi oleh faktor eksternal seperti tugas-tugas yang dilakukan yang bersifat fisik, organisasi kerja, dan lingkungan kerja serta faktor internal yaitu faktor yang berasal dari dalam tubuh akibat dari reaksi beban kerja eksternal.reaksi tubuh disebut strain, berat ringannya strain dapat dinilai baik secara objektif maupun subjektif.

\section{Hubungan Beban Kerja Terhadap Prestasi Kerja}

Hubungan beban kerja Terhadap prestasi kerja disampaikan oleh beban kerja yang terlalu berlebihan akan menimbulkan kelelahan baik fisik maupun mental dan reaksi-reaksi emosional. Sedangkan pada beban kerja yang sangat sedikit dimana pekerjaan yang terjadi karena pengurangan gerak akan menimbulkan kebosanan dan rasa monoton. Kebosanan dalam kerja rutin sehari-hari karena tugas atau pekerjaan yang terlalu sedikit mengakibatkan kurangnya perhatian pada pekerjaan sehingga secara potensial membahayakan pekerja dan akan menurunkan prestasi kerja seseorang, yang akan membahayakan suatu organisasi (Adhani 2013).

Maslow dalam (hariandja 2002) ada 5 kebutuhan dasar yang membentuk hirarki kebutuhan yang dapat meningkatkan motivasi seorang pekerja untuk terus berprestasi yaitu kebutuhan aktualisasi diri. 
Manuaba dalam (2007) beban kerja yang terlalu berlebihan akan menimbulkan kelelahan baik fisik maupun mental dan reaksi-reaksi emosional seperti sakit kepala, gangguan pencernaan dan mudah marah. Sedangkan beban kerja yang terlalu sedikit dimana pekerjaan yang terjadi karena pengurangan gerak akan menimbulkan kebosanan dan rasa monoton.

\section{METODE PENELITIAN}

\section{Jenis Penelitian}

Jenis penelitian ini menggunakan metode kuantitatif. Metode kuantitatif merupakan metode yang data penelitiannya berupa angka-angka dan analisis menggunakan statistik (Sugiyono, 2015:13).

\section{Objek dan Lokasi Penelitian}

Objek penelitian adalah variabel atau segala sesuatu yang menjadi pusat perhatian seseorang dalam melakukan sebuah penelitian (Sugiyono, 2015). Objek dari penelitian ini adalah pada Dinas Perindustrian dan Perdagangan sumatera barat. Lokasi penelitian ini berada di Jl. Aur No. 1, Padang Barat, Kota Padang,Sumatera Barat.

\section{Populasi dan Sampel \\ Populasi}

Populasi adalah wilayah generalisasi yang terdiri atas: obyek/subyek yang mempunyai kuantitas dan karakteristik tertentu yang ditetapkan oleh peneliti untuk dipelajari dan ditarik kesimpulannya (Sugiyono, 2015:92). Populasi dalam penelitian ini adalah 41 orang.

\section{Sampel}

Sampel adalah bagian dari jumlah dan karakteristik yang dimiliki oleh populasi (Sugiyono, 2015:93). Keseluruhan populasi tidak mungkin dapat diteliti karena keterbatasan biaya, tenaga,dan waktu. Oleh karena itu, teknik pengambilan sampel yang digunakan dalam penelitian ini adalah Sampel jenuh. Sampel jenuh yaitu teknik penentuan sampel bila semua anggota populasi digunakan sebagai sampel. hal ini sering dilakukan bila populasi relatif kecil. Jadi populasi penelitian ini yang diambil sebanyak 41 orang yang memiliki kriteria tertentu.

\section{Jenis dan Sumber Data \\ Jenis Data}

Data yang digunakan dalam penelitian ini adalah data kuantitatif. Data kuantitatif adalah data yang berbentuk angka atau data kualitatif yang diangkakan/scoring (Sugiyono, 2015:7).

\section{Defenisi Operasional Variabel}

Variabel yang digunakan dalam penelitian ini adalah variabel bebas (independent variabel) dan variabel terikat (dependent variabel)

\section{Variabel Bebas (Independent Variabel)}

Menurut Sugiyono, (2015:41) variable bebas adalah variabel yang mempengaruhi atau yang menjadi sebab perubahannya atau timbulnya kegiatan yang mempunyai variable dependen (variabel terikat). Adapun yang menjadi variabel bebas dalam penelitian ini adalah kebutuhan aktualisasi diri dan bebankerja. 


\section{Variabel Terikat (Dependent Variabel)}

Variabel terikat merupakan variabel yang dipengaruhi atau yang menjadi akibat, karena adanya variable bebas (Sugiyono, 2015:41). Adapun variabel terikat yang digunakan dalam penelitian ini adalah prestasi kerja karyawan.

Tabel 1

Defenisi Operasional Variabel

\begin{tabular}{|c|c|c|c|}
\hline $\begin{array}{l}\text { Variabel } \\
\text { Penelitian }\end{array}$ & Defenisi & Indikator & Sumber \\
\hline $\begin{array}{l}\text { Kebutuhan } \\
\text { Aktualisasi } \\
\text { Diri } \\
\text { (X1) }\end{array}$ & $\begin{array}{lr}\text { aktualisasi diri } \\
\text { adalah proses } \\
\text { implementasi } \\
\text { seorang individu dari } \\
\text { minat, kreativitas, } \\
\text { keinginan untuk } \\
\text { berkembang, } \\
\text { kemampuan untuk } \\
\text { bertanggung jawab } \\
\text { dan kemandirian. }\end{array}$ & $\begin{array}{l}\text { 1.Kebutuhan } \\
\text { pertumbuhan. } \\
\text { 2.Kebutuhan } \\
\text { pencapaian } \\
\text { potensi } \\
\text { seseorang } \\
\text { 3.Kebutuhan } \\
\text { pemenuhandiri } \\
\text { 4.Kebutuhandor } \\
\text { ongan }\end{array}$ & $\begin{array}{l}\text { (Rumbiat, } \\
\text { 2016) }\end{array}$ \\
\hline $\begin{array}{c}\text { Beban } \\
\text { Kerja } \\
\text { (X2) }\end{array}$ & 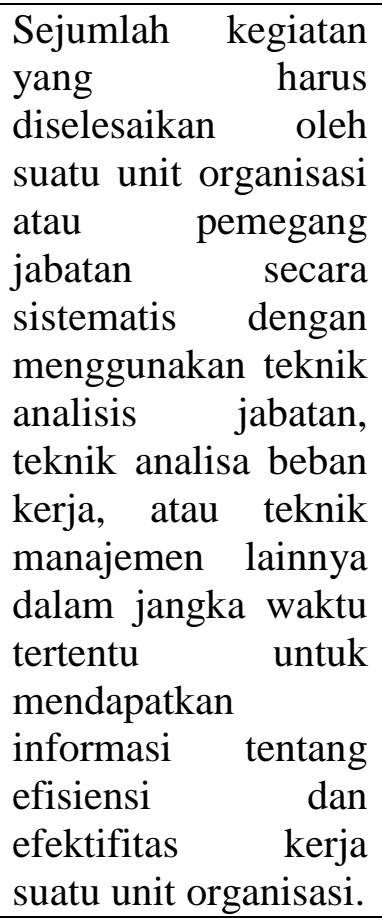 & $\begin{array}{ll}\text { 1. Jam } & \text { kerja } \\
\text { efektif } & \\
\text { 2. } & \text { Latar } \\
\text { Belakang } & \\
\text { Pendidikan } & \\
\text { 3. } & \text { Jenis } \\
\text { pekerjaan } & \text { yang } \\
\text { diberikan } & \end{array}$ & $\begin{array}{l}\text { (Julia } \\
\text { Anita, } \\
2013)\end{array}$ \\
\hline $\begin{array}{c}\text { Prestasi } \\
\text { Kerja } \\
\text { Karyawan } \\
\text { (Y) }\end{array}$ & $\begin{array}{lr}\text { prestasi } & \text { kerja } \\
\text { sebagai } & \text { tingkat } \\
\text { keberhasilan } & \text { yang } \\
\text { dicapai } & \text { seseorang } \\
\text { untuk mengetahui } \\
\text { sejauh }\end{array}$ & $\begin{array}{l}\text { 1. Kemampuan } \\
\text { kerja } 2 . \\
\text { Penggunaan } \\
\text { waktu kerja } \\
\text { 3. Hasil yang } \\
\text { diharapkan } \\
\text { 4. Sikap ingin } \\
\text { meningkatkan } \\
\text { kemampuan }\end{array}$ & $\begin{array}{l}\text { (Julia } \\
\text { Anita, } \\
2013)\end{array}$ \\
\hline
\end{tabular}




\section{Teknik Analisis Data}

\section{Uji Validitas}

Uji validitas digunakan untuk mengukur sah atau valid tidaknya suatu kuisioner. Suatu kuisioner dikatakan valid jika pertanyaan pada kuisioner mampu untuk mengungkap sesuatu yang akan diukur oleh kuisioner tersebut (Weenas et al., 2013). Menurut Hariadi \& Martoatmodjo (2012) dasar pengambilan keputusan uji validitas adalah sebagai berikut:

a. Jika $r$ hasil positif, serta $r$ hasil $>r$ tabel, maka hal ini berarti bahwa butir atau item pertanyaan tersebut valid.

b. Jika $r$ hasil negatif, dan $r$ hasil $<r$ tabel maka hal ini berarti bahwa butir atau item pertanyaan tersebut tidak valid.

\section{Uji Reliabilitas}

Menurut Saidani \& Arifin (2012) Uji reliabilitas berguna untuk menetapkan apakah instrumen, dalam hal ini kuisioner, dapat digunakan lebih dari satu kali, paling tidak oleh responden yang sama. Uji reliabilitas untuk alternative jawaban lebih dari dua menggunakan uji cronbach's alpha, yang nilainya akan dibandingkan dengan nilai koefisien reliabilitas minimal yang dapat diterima. Reliabilitas kurang dari 0.6 adalah kurang baik, sedangkan 0.7 dapat diterima, dan lebih dari 0.8 adalah baik. Dari pengambilan keputusan uji reliabilitas adalah sebagai berikut:

Jika nilai cronbach's alpha $>0.6$, maka instrument penelitian reliabel.

Jika nilai cronbach's alpha $<0.6$, maka instrument penelitian tidak reliabel.

\section{Uji Total Capaian Responden (TCR)}

Menghitung nilai Tingkat Capaian Responden (TCR) masingmasing kategori dari data deskriptif variabel.

Rumus yang digunakan yaitu (Hanum et al., 2015):

$$
T C R=\frac{R s}{\mathrm{n}} \times 100 \%
$$

Keterangan :

TCR $=$ Tingkat Capaian Responden

Rs = Rata-rata skor jawaban responden

$\mathrm{n} \quad=$ Nilai skor jawaban

Kriteria interpretasi skor untuk Tingkat Capaian Responden (TCR) adalah sebagai berikut:

Tabel 2

Rentang Skala TCR

\begin{tabular}{|c|c|c|}
\hline No & Angka & Keterangan \\
\hline 1 & $00 \%-20 \%$ & Sangat Tidak Setuju \\
\hline 2 & $21 \%-40 \%$ & Tidak Setuju \\
\hline 3 & $41 \%-60 \%$ & Kurang Setuju \\
\hline 4 & $61 \%-80 \%$ & Setuju \\
\hline 5 & $81 \%-100 \%$ & Sangat Setuju \\
\hline
\end{tabular}

Sumber: Hanum et al., (2015) 


\section{PEMBAHASAN \\ Uji Regresi Linear Berganda}

Analisis regresi berganda dalam penelitian ini dilakukan dengan menggunakan bantuan program SPSS Versi 24.0 dapat dilihat pada Tabel dibawah ini :

Tabel 3

Hasil Analisis regresi Berganda Coefficients $^{\mathrm{a}}$

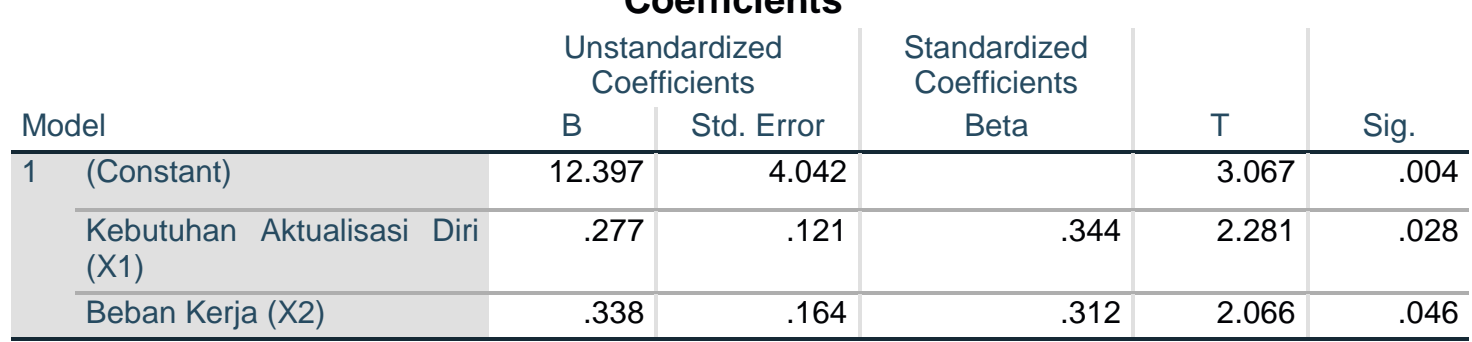

a. Dependent Variable: Prestasi kerja (Y)

Sumber: Data Primer diolah dengan SPSS Th.2018

Berdasarkan hasil yang terdapat pada Tabel 4.15di atas, maka dapat dirumuskan persamaan regresi linear berganda sebagai berikut:

$$
\begin{aligned}
& \mathrm{Y}=\mathrm{a}+\mathrm{b}_{1} \mathrm{X}_{1}+\mathrm{b} 2 \mathrm{X} 2+\mathrm{e} \\
& \mathrm{Y}=12,397+0,277 \mathrm{X}_{1}+338 \mathrm{X}_{2}+\mathrm{e}
\end{aligned}
$$

1. Dari model persamaan regresi linear berganda di atas dapat diketahui bahwa nilai konstanta sebesar 12,397, yang berarti bahwa tanpa adanya pengaruh dari variable kebutuhan aktualisasi diri dan beban kerja maka prestasi kerja sudah mencapai 12,239 satuan.

2. Koefisien regresi variabel kebutuhan aktualisasi diri $\left(\mathrm{X}_{1}\right)$ sebesar 0,277. Hal ini berarti apabila kebutuhan aktualisasi dirimeningkat sebesar satu satuan maka prestasi kerjaakan meningkat sebesar 0,277 dalam setiap satuannya. Dengan asumsi variabel lain tidak mengalami perubahan atau konstan.

3. Koefisien regresi variabel beban kerja $\left(\mathrm{X}_{2}\right)$ sebesar 338 . Hal ini berarti apabila beban kerjameningkat sebesar satu satuan maka prestasi kerjaakan meningkat sebesar 338.dalam setiap satuannya. Dengan asumsi variabel lain tidak mengalami perubahan atau konstan.

\section{Koefisien Determinasi $\mathbf{R}^{\mathbf{2}}$}

Koefisien determinasi bertujuan untuk mengukur seberapa jauh kemampuan model dalam menerangkan variasi variabel dependen.

\section{Tabel 4}

\section{Hasil Analisis Koefisien Determinasi R2

\begin{tabular}{|c|c|c|c|c|}
\hline Model & $\mathrm{R}$ & R Square & Adjusted R Square & Std. Error of the Estimate \\
\hline 1 & $.560^{\mathrm{a}}$ & .314 & .278 & 3.750 \\
\hline
\end{tabular} Model Summary}

a. Predictors: (Constant), Beban Kerja (X2), Kebutuhan Aktualisasi Diri (X1)

b. Dependent Variable: Prestasi kerja (Y)

Sumber: Data Primer diolah dengan SPSS Th.2018

Berdasarkan tabel 4.16 diatas dapat terlihat bahwa besarnya nilai $\mathrm{R}$ Square (dilihat dari Adjusted R square) sebesar 0,278. Hal ini berarti 27,8\% prestasi kerja dipengaruhi oleh kebutuhan aktualisasi diri dan beban kerja 
sedangkan sisanya 72,2\% disebabkan oleh hal-hal lain yang ada diluar penelitian seperti lingkungan kerja dan motivasi kerja.

\section{Uji Hipotesis (Uji T)}

Uji T dilakukan untuk melihat apakah ada pengaruh yang signifikan atau tidak secara parsial antara kebutuhan aktualisasi diri dan beban kerja terhadap prestasi kerja.Adapun hasilnya dapat dilihat pada tabel.

\begin{tabular}{|c|c|c|c|c|c|c|}
\hline \multirow{3}{*}{\multicolumn{2}{|c|}{ Model }} & \multicolumn{3}{|c|}{$\begin{array}{c}\text { Tabel } 5 \\
\text { Hasil Analisis Uji T } \\
\text { Coefficients }^{\mathbf{a}}\end{array}$} & \multirow[b]{3}{*}{$\mathrm{t}$} & \multirow[b]{3}{*}{ Sig. } \\
\hline & & \multicolumn{2}{|c|}{$\begin{array}{l}\text { Unstandardized } \\
\text { Coefficients }\end{array}$} & \multirow{2}{*}{$\begin{array}{l}\text { Standardized } \\
\text { Coefficients } \\
\text { Beta }\end{array}$} & & \\
\hline & & B & Std. Error & & & \\
\hline & (Constant) & 12.39 & 4.042 & & 3.067 & .004 \\
\hline & $\begin{array}{l}\text { Kebutuhan Aktualisasi Diri } \\
\text { (X1) }\end{array}$ & .27 & .121 & .344 & 2.281 & .028 \\
\hline & Beban Kerja (X2) & .33 & .164 & .312 & 2.066 & .046 \\
\hline
\end{tabular}

a. Dependent Variable: Prestasi kerja $(\mathrm{Y})$

Sumber: Data Primer diolah dengan SPSS Th.2018

Berdasarkan hasil pengolahan data diatas pada tabel 4.17 hasil uji $\mathrm{t}$ parsial, maka dapat disimpulkan bahwa:

1. Dari tabel diatas terlihat bahwa kebutuhan aktualisasi diri memiliki nilai koefisien regresi positif dengan nilai t hitung sebesar 12,397 dengan nilai sig sebesar 0,028. Jika dibandingkan dengan ( $\mathrm{t}$ tabel, sig 0.05, df (41-2) $=$ 39. Maka dapat terlihat bahwa dengan nilai $t$ hitung 2,281> t tabel 2,024, dan nilai sig $0,028<0.05$, maka dapat disimpulkan bahwa Ha diterima dan Ho ditolak artinya bahwa kebutuhan aktualisasi diri berpengaruh dan signifikan terhadap prestasi kerja karyawan.

2. Dari tabel diatas terlihat bahwa beban kerja memiliki nilai koefisien regresi positif dengan nilai t hitung sebesar 2,066 dengan nilai sig sebesar 0,046. Jika dibandingkan dengan ( $\mathrm{t}$ tabel, sig 0.05, df $(41-2)=39$ ). Maka dapat terlihat bahwa dengan nilai t hitung 2,066, $>\mathrm{t}$ tabel 2,024, dan nilai sig $0,046<0.05$, maka dapat disimpulkan bahwa Ha diterima dan Ho ditolak artinya bahwa beban kerja berpengaruh dan signifikan terhadap keputusan prestasi kerja.

Berdasarkan hasil penelitian tentang pengaruh kebutuhan aktualisasi diri berpengaruhterhadap prestasi kerja karyawan pada Dinas Perindustrian dan Perdagangan sumatera barat, maka pembahasan dapat diberikan sebagai berikut:

Pengujian kebutuhan aktualisasi diriterhadap prestasi kerja karyawan pada Dinas Perindustrian dan Perdagangan Sumatera Barat.

Berdasarkan penelitian diperoleh hasil kebutuhan aktualisasi diri memiliki nilai koefisien regresi positif dengan nilai t hitung sebesar 12,397 dengan nilai sig sebesar 0,028. Jika dibandingkan dengan ( t tabel, sig 0.05, df $(41-2)=39$. Maka dapat terlihat bahwa dengan nilai $t$ hitung 2,281 $>\mathrm{t}$ tabel 2,022, dan nilai sig 0,028<0.05, maka dapat disimpulkan bahwa Ha diterima dan Ho ditolak artinya bahwa kebutuhan aktualisasi diri berpengaruh dan signifikan terhadap prestasi kerja karyawan.

Sejalan dengan penelitian sebelumnya yang dilakukan oleh Adhani (2013) dengan judul "Pengaruh Kebutuhan Aktualisasi Diri Dan Beban 
Kerja Terhadap Prestasi Kerja Karyawan " mengatakan Aktualisasi Diri berpengaruh signifikan terhadap Prestasi Kerja Karyawan dan penelitian dan Hal ini didukung oleh penelitian yang dilakukan oleh Shasha, (2018) tentang pengaruh kebutuhan aktualisasi diri, beban kerja dan kemampuan kerja terhadap prestasi kerja diperoleh hasil nilai sig 0,000<0,05 artinya terdapat pengaruh kebutuhan aktualisasi diri terhadpa prestasi kerja pegawai di Balai Wilayah Sungai Kalimantan III Dinas PU Prov.Kaltim.

Pemenuhan kebutuhan akan aktualisasi diri merupakan tingkat kebutuhan yang tertinggi dari teori Maslow (1970) dalam Adhani, (2013) bahwa ketika seseorang telah tercukupi dalam ke-4 kebutuhan di bawahnya maka ia pun akan membutuhkan aktualiasi diri dimana ia diakui sebagai seseorang yang memiliki kontribusi penting atas sebuah perusahaan. Jika kebutuhan kebutuhan tersebut dapat diberikan oleh pihak perusahaan, maka prestasi karyawan diharapkan akan meningkat, dan memberikan keuntungan terhadap perusahaan.

Hal ini sejalan dengan penelitian yang dilakukan oleh Dito (2012) yang mengemukakn bahwa kinerja karyawan yang baik tumbuh dari motivasi yang tinggi, dimana motivasi yang tinggi tumbuh dari bagaimana perusahaan memperlakukan karyawannya, yaitu dengan memberikan berupa gaji, bonus tunjangan dan berbagai fasilitas yang memadai. Dengan adanya hal tersebut para karyawan merasa dihargai dan didukung dalam bekerja.

Pengujian beban kerja terhadap prestasi kerja karyawan pada Dinas Perindustrian dan Perdagangan Sumatera Barat.

Berdasarkan penelitian diperoleh hasil beban kerja memiliki nilai koefisien regresi positif dengan nilai t hitung sebesar 2,066 dengan nilai sig sebesar 0,046. Jika dibandingkan dengan ( $\mathrm{t}$ tabel, sig 0.05, df (41-2) = 39). Maka dapat terlihat bahwa dengan nilai t hitung 2,066, > t tabel 2,022, dan nilai sig $0,046<0.05$, maka dapat disimpulkan bahwa Ha diterima dan Ho ditolak artinya bahwa beban kerja berpengaruh dan signifikan terhadap keputusan prestasi kerja.

Sejalan dengan penelitian sebelumnya yang dilakukan oleh Shasha, (2018) tentang pengaruh kebutuhan aktualisasi diri, beban kerja dan kemampuan kerja terhadap prestasi kerja diperoleh hasil nilai sig $0,001<0,05$ artinya terdapat pengaruh beban kerja terhadap prestasi kerja pegawai di Balai Wilayah Sungai Kalimantan III Dinas PU Prov.Kaltim

Hubungan beban kerja terhadap prestasi kerja disampaikan oleh beban kerja yang terlalu berlebihan akan menimbulkan kelelahan baik fisik maupun mental dan reaksi-reaksi emosional. Sedangkan pada beban kerja yang sangat sedikit dimana pekerjaan yang terjadi karena pengurangan gerak akan menimbulkan kebosanan dan rasa monoton. Kebosanan dalam kerja rutin sehari-hari karena tugas atau pekerjaan yang terlalu sedikit mengakibatkan kurangnya perhatian pada pekerjaan sehingga secara potensial membahayakan pekerja dan akan menurunkan prestasi kerja seseorang, yang akan membahayakan suatu organisasi (Adhani 2013).

Hal ini didukung penelitian yang dilakukan oleh Mudayana (2012) yang menyatakan bahwa karyawan akan tetap bekerja dengan baik meskipun beban kerja yang diterima tinggi atau sedang, selama mereka 
masih termotivasi dalam bekerja. Akan tetapi, beban kerja yang diterima karyawan juga tetap perlu diperhatikan meskipun tidak berpengaruh terhadap kinerja mereka Agar tidak terjadi beban kerja yang terlalu tinggi yang dapat menimbulkan stres yang berdampak pada kinerja karyawan.

\section{SIMPULAN}

Berdasarkan hasil pengujian dan pembahasan mengenai Pengaruh Kebutuhan Aktualisasi Diri Dan Beban Kerja Terhadap Prestasi Kerja Karyawan Pada Dinas Perindustrian Dan Perdagangan Sumatera Barat, maka dapat ditarik kesimpulan, antara lain:

1. kebutuhan aktualisasi diri memiliki nilai koefisien regresi positif dengan nilai $t$ hitung sebesar 12,397 dengan nilai sig sebesar 0,028. Jika dibandingkan dengan ( $\mathrm{t}$ tabel, sig 0.05, df $(41-2)=39$. Maka dapat terlihat bahwa dengan nilai $\mathrm{t}$ hitung 2,281 $>\mathrm{t}$ tabel 2,024 , dan nilai sig $0,028<0.05$, maka dapat disimpulkan bahwa Ha diterima dan Ho ditolak artinya bahwa kebutuhan aktualisasi diri berpengaruh dan signifikan terhadap prestasi kerja karyawan.

2. beban kerja memiliki nilai koefisien regresi positif dengan nilai t hitung sebesar 2,066 dengan nilai sig sebesar 0,046. Jika dibandingkan dengan $(\mathrm{t}$ tabel, sig 0.05, df $(41-2)=39)$. Maka dapat terlihat bahwa dengan nilai $\mathrm{t}$ hitung 2,066, > t tabel 2,024, dan nilai sig 0,046< 0.05, maka dapat disimpulkan bahwa Ha diterima dan Ho ditolak artinya bahwa beban kerja berpengaruh dan signifikan terhadap keputusan prestasi kerja.

\section{DAFTAR PUSTAKA}

S. (2016). Pengaruh Kebutuhan Fisiologis, Keamanan, Sosial, Penghargaan, Dan Aktualisasi Diri Terhadap Prestasi Kerja Karyawan (Studi Pada Karyawan Pt. Asuransi Jiwasraya (Persero) Malang Regional Office, 30(1), 109-116.

Adhani, A. R. (2013). Pengaruh Kebutuhan Aktualisasi Diri Dan Beban Kerja Terhadap Prestasi Kerja Karyawan. Jurnal Ilmu Manajemen, 1(1).

Anita, J. (2013). Pengaruh Penempatan Dan Beban Kerja Terhadap Motivasi Kerja Dan Dampaknya Pada Prestasi Kerja Pegawai Dinas Tenaga Kerja Dan Mobilitas Penduduk Aceh Julia, 2(1), 67-77.

Desriana, A. (2014). "Pengaruh Budaya Organisasi, Aktualisasi Diri, Dan Penghargaan Terhadap Prestasi Kerja Karyawan Pt. Kereta Api Indonesia (Persero) Daop Iv Semarang."

Dona, E. (2016). Pengaruh Perencanaan, Prosedur Dan Pengawasan dan Komitmen Organisasi Dalam Pelaksanaan Anggaran Terhadap Kinerja Pegawai Dinas Pekerjaan Umum Kota Pariaman. Jurnal Riset Manajemen dan Akuntansi (Jurmak), 23-35

Dona, E. (2018). Analisis Motivasi Kerja Ditinjau Dari Lingkungan Kerja Kasus Karyawan LBPP Lia Payakumbuh. Jurnal KBP

Emita, S., \& Magdalena, M. (2019). Atribut Produk Yang Dipertimbangkan Dalam Pembelian Kosmetik Wardah Dan Pengaruhnya Pada Kepuasan Mahasiswa Jurusan Manajemen Stie "Kbp" Padang. Https://Doi.Org/10.31219/Osf.Io/872ds

F., \& Magdalena, M. (2019). Pengaruh Komunikasi Lisan Dari Dokter Hewan

Terhadap Kepuasan Pelanggan Pada Produk Obat Di Pt Sanbe Farma Cabang 
Padang. Https://Doi.Org/10.31219/Osf.Io/Rgs5

Fatra, O., \& Magdalena, M. (2020, March 23). Pengaruh Pengembangan Karier,

Penempatan Jabatan dan Motivasi Terhadap Prestasi Kerja Pegawai Pada

Kantor Camat Kubung. https://doi.org/10.31219/osf.io/ts94j

Lituhayu, R. (2008). Analisis Beban Kerja Dan Kinerja Karyawan (Studi Kasus

Pada Head Office) Pt Lerindro Internasional Jakarta. Ilmu Manajemen.

Marlius, D. RD Putra. (2018). Strategi Pengembangan Sulam Bayang. Jurnal

Benefita: Ekonomi Pembangunan Manajemen Bisnis Dan Akuntansi.

Volume 3. No. 2. Hal. 204-218. http://doi.org/10.22216/jbe.v3i2.3494

Nardo, R. Evanita, Syahrizal, S. (2018). Pengaruh Kepemimpinan Transformasional, Dan Lingkungan Kerja Non Fisik Terhadap Perilaku Inovatif. JEBI (Jurnal Ekonomi dan Bisnis Islam) 3 (2), 209-215

Nardo, R. Evanita, Syahrizal, S. (2019). The Effect of Transformational Leadership and Non Physical Work Environment on Innovative Behavior with Work Motivation as a Mediation For Employees of Tour And Travel Companies In West Sumatera. 2nd Padang International Conference on Education, Economics, Business and Accounting (PICEEBA-2 2018)

Putra, RY. Marlius, D. (2019). Pengaruh Pendidikan, Pengalaman Kerja dan Etos Kerja Terhadap Kinerja Pegawai Di KPN Batur. Academic Conference For Management 2.

Rahmizal, M. (2018). Pengaruh Pendapatan, Pendidikan, Kesehatan, Modal Sosial Dan Religiusitas Terhadap Kebahagiaan Individu Di Indonesia. Universitas Gadjah Mada

Susriyanti, S. Nardo, R. (2019). Pengaruh Fungsi Komunikasi Dan Kepuasan Kerja Karyawan Terhadap Pemberian Pelayanan Nasabah PT. BPR LPN Talawi Sakato. Jurnal Administrasi Sosial dan Humaniora 3 (2), 97-111.

Yudistira, D. S., \& Susanti, F. (2019). Pengaruh Motivasi Kerja Dan Budaya Kerja Terhadap Kinerja Karyawan Dinas Pemberdayaan Masyarakat Dan Desa, Pengendalian Penduduk Dan Keluarga Berencana Kabupaten Pesisir Selatan. https://doi.org/10.31227/osf.io/jk54m

Mulyadi, H., \& Susanti, F. (2018). Pengaruh Penerapan Strategi Customer Relationship Marketing Terhadap Kepuasan Nasabah Pada PT. Pro Car International Finance Cabang Padang. https://doi.org/10.31227/osf.io/bhq8d

Ridho, M., \& Susanti, F. (2019). Pengaruh Stres Kerja Dan Motivasi Kerja Terhadap Kepuasan Kerja Pada Karyawan Bank Mandiri Syariah Cabang Padang. https://doi.org/10.31227/osf.io/pa2cg

Lubis, A. Y. O., \& Susanti, F. (2019). Pengaruh Gaya Kepemimpinan Dan Kompensasi Terhadap Prestasi Kerja Karyawan (Studi pada PT Japfa Comfeed Indonesia (JCI) Tbk Devisi Fam 1. https://doi.org/10.31227/osf.io/7tbrg

Aldi, Y., \& Susanti, F. (2019). Pengaruh Stress Kerja Dan Motivasi Kerja Terhadap Prestasi Kerja Karyawan Pada PT. Frisian Flag Indonesia Wilayah Padang. https://doi.org/10.31227/osf.io/et4rn

Widodo, B. H., \& Susanti, F. (2019). Pengaruh Human Relation (Hubungan Antar Manusia), Lingkungan kerja Terhadap Etos Kerja karyawan (Studi Kasus Pada PT. Pelindo Teluk Bayur Padang). https://doi.org/10.31227/osf.io/dxm8a

Junaidi, R., \& Susanti, F. (2019). Pengaruh Gaya Kepemimpinan Dan Budaya 
Organisasi Terhadap Kinerja Pegawai Pada UPTD Baltekkomdik Dinas Pendidikan Provinsi Sumatera Barat. https://doi.org/10.31227/osf.io/bzq75

Samosir, F., \& Magdalena, M. (2019). Effect Of Work Stress And Work

Satisfaction Of Employees Performance Pt. Primatama Mulia Jaya Iv Koto Kinali Kecamatan Kinali Kab. Pasaman Barat. Https://Doi.Org/10.31219/Osf.Io/Gjvry

Sugiyono. (2015). Statistik Nonparametriks Untuk Penelitian. Bandung: Alfabeta. Sugiyono. (2015). Statistik Nonparametris Untuk Penelitian. Yogyakarta.

Yusianto, R. (2008). Analisa Pengaruh Stres Kerja Terhadap Prestasi Kerja Staf Pengajar (Studi Kasus Fakultas Ilmu Komputer Universitas Dian Nuswantoro Semarang). Isbn, 151-157. 